
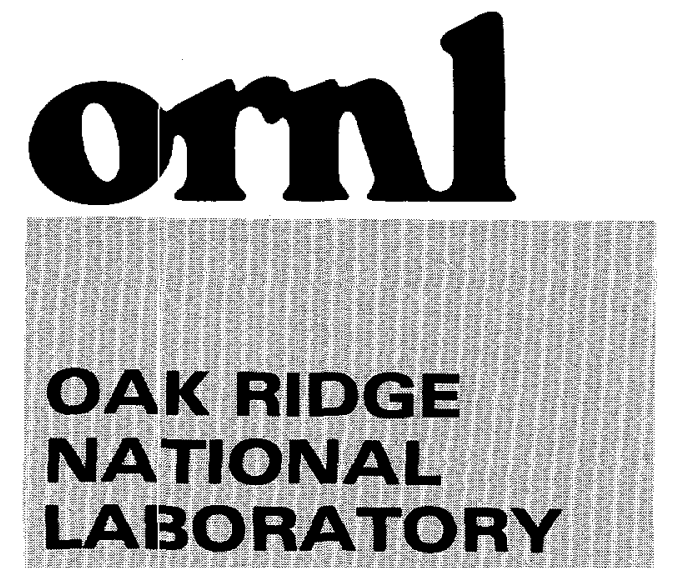

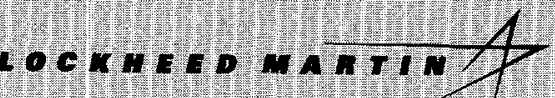
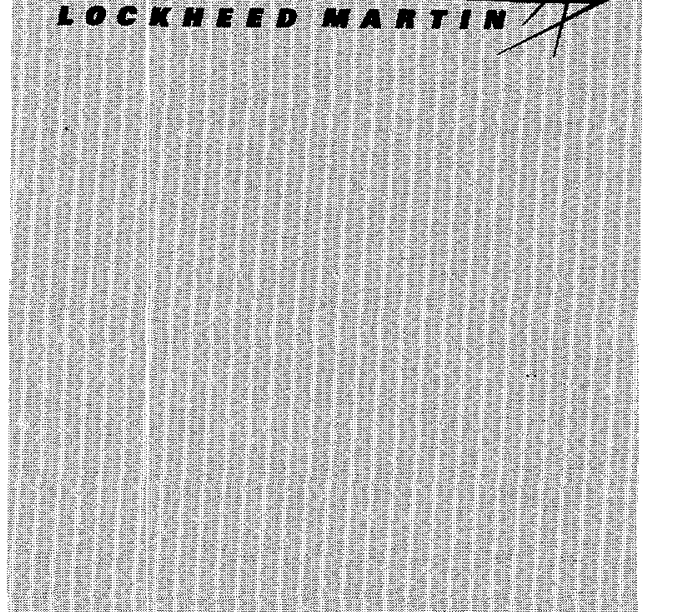

1)
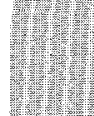

1.t.
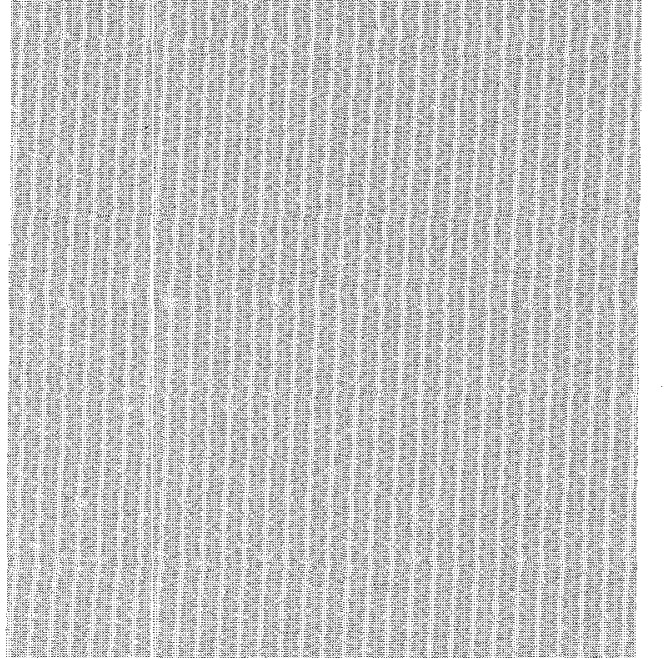

WANAGED AND OPERATED BY LOCKHEED MARTW ENERGY RESEARCH CORPORATION FOA THE UULTED STATES: DEPARTMENT OF ENERGY

\section{RECEIVED \\ Jiti 19 998RADA Final Report for \\ $O \&$ CRADA Number ORNL 95-0344}

Development of Aluminum Bridge Deck System with Reynolds Metals Company

Final Report

\author{
C. R. Brinkman \\ W. H. Hayden \\ Oak Ridge National Laboratory \\ P. O. Box 2008 \\ Oak Ridge, TN 37831-6152
}

Prepared by the Oak Ridge National Laboratory Oak Ridge, Tennessee 37831-6285 managed by

Lockheed Martin Energy Research Corporation for the

U.S. Department of Energy under contract DE-AC05-96OR22464

APPROVED FOR PUBLIC RELEASE UNLIMITED DISTRIBUTION 
This report has been reproduced directly from the best available copy.

Available to DOE and DOE contractors from the Office of Scientific and Technical Information, P.O. Box 62, Oak Ridge, TN 37831; prices available from (423) $576-8+01$.

Available to the public from the National Technical Information Service, U.S. Department of Commerce, 5285 Port Royal Rd., Springfield, VA 22161

This report was prepared as an account of work sponsored by an agency of the United State Government. Neither the United State Government nor any agency thereof, nor any of their employees, makes any warranty, express or implied, or assumes any legal liability or responsibility for the accuracy. completeness, or usefulness of any information, apparatus, product or process disclosed, or represents that its use would not infringe privately owned rights. Reference herein to any specific commercial product, process, or service by trade name, trademark, manufacturer, or otherwise, does not necessarily constitute or imply its endorsement, recommendation, or favoring by the United States Government or any agency thereof. The views and opinions of authors expressed herein do not necessarily state or reflect those of the United States Government or any agency thereof. 


\section{DISCLAIMER}

Portions of this document may be illegible in electronic image products. Images are produced from the best available original document. 
CRADA FINAL REPORT FOR CRADA NUMBER ORNL 95-0344

\title{
DEVELOPMENT OF ALUMINUM BRIDGE DECK SYSTEM WITH REYNOLDS METALS COMPANY
}

FINAL REPORT

\author{
C. R. Brinkman \\ W. H. Hayden
}

Date Published: April 1999

\author{
Prepared by the \\ Oak Ridge National Laboratory \\ Oak Ridge, Tennessee 37831-6285 \\ managed by \\ Lockheed Martin Energy Research Corporation \\ for the \\ U.S. Department of Energy \\ under contract DE-AC05-960R22464
}




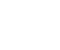




\section{CONTENTS}

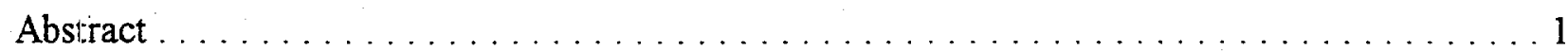

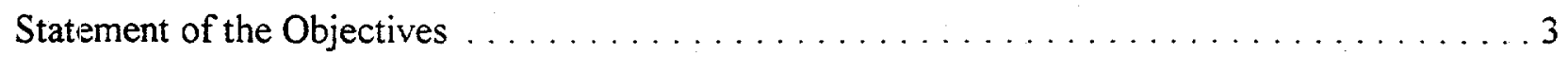

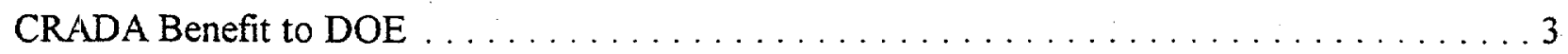

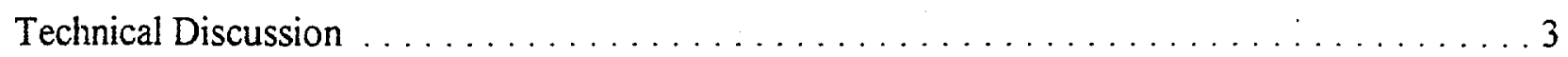

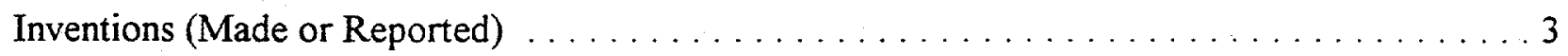

Commercialization Possibilities $\ldots \ldots \ldots \ldots \ldots \ldots \ldots \ldots \ldots \ldots \ldots \ldots \ldots$

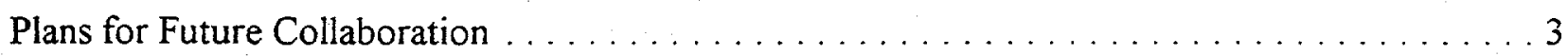

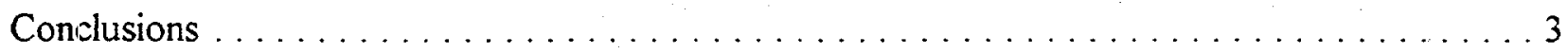

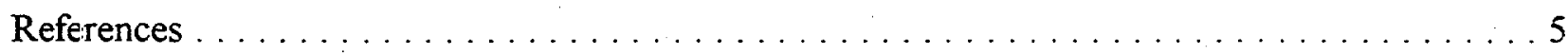

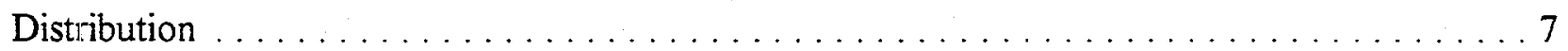





\title{
DEVELOPMENT OF ALUMINUM BRIDGE DECK SYSTEM WITH REYNOLDS METALS COMPANY
}

\author{
C. R. Brinkman and H. Wayne Hayden* \\ Oak Ridge National Laboratory
}

\begin{abstract}
Currently, there are many structurally-deficient and obsolete bridges in the U.S. highway system. The expected cost for repair and replacement is enormous; therefore, more cost-effective materials and construction methodology must be sought. Reynolds Metals Company * formed a vertical consortium to develop and market a cost-effective, innovative, lightweight, corrosion resistant aluminum bridge deck system based on hollow aluminum shapes that could be welded together in the shop to form deck panels. Panels would be shipped to the construction sites for final assembly, which uses connections along longitudinal edges. ${ }^{1}$ These deck panels would replace conventional steel or concrete panels. An epoxy-gravel wearing surface would be applied to the top side of the deck to provide a durable, skid-resistant surface. However, before this deck system could be widely utilized, the overall structural integrity had to be fully demonstrated. Reynolds Metals Company and Oak Ridge National Laboratory (ORNL) entered into a Cooperative Research and Development Agreement (CRADA) to conduct a number of fundamental investigations into potentially critical technical areas over approximately a four-year period. The technical areas that were investigated at ORNL were selected to take advantage of unique talents and capabilities, and were as follows:
\end{abstract}

High cycle fatigue tests were conducted on candidate mechanical deck-to-bridge joints using four different fasteners to determine fatigue lives under tension-tension loading. ${ }^{2}$

Through thickness residual strain mapping, studies were conducted using neutron diffraction on a welded joint between two aluminum sections that comprise the deck structure. ${ }^{3}$

Wearing integrity tests were conducted on aluminum and resin-rock (pea gravel) surface coated samples to determine if the wear surface would remain attached to the deck under normal service conditions. Bending high cycle fatigue tests were conducted at temperatures of $-20^{\circ} \mathrm{F}$ to $150^{\circ} \mathrm{F}$. Resin cure time, mixture ratios, wear surface thickness, and aluminum surface preparation were also varied. Ultimate and endurance limits were determined. ${ }^{4.5}$ Ultrasonic scans were used to characterize debonding that occurred in localized areas between the aluminum and resin.

Turn-of-nut method was investigated to determine the integrity of proposed slip-critical bolted aluminum joints to be used to assemble aluminum bridge deck sections. These studies showed that the same rules used in tightening bolts in steel structures were also applicable to aluminum structures. ${ }^{5}$

Bending fatigue studies were conducted on welded aluminum plates to simulate loading conditions in aluminum bridge deck system weldments. Weld defects were introduced prior to testing either during the weld process or by machining. Degradation in fatigue life occurred as a result of these defects and the reduction in life was dependent upon defect length.

* This work was supported through a Cooperative Research and Development Agreement with Reynolds Metals Company (Richrnond, Virginia), sponsored by the Laboratory Technology Program, Office of Energy Research, U.S. Department of Energy, under contract DE-AC05-960R22464 with Lockheed Martin Energy Research Corporation. 



\section{STATEMENT OF THE OBJECTIVES}

To perform materials and structures testing and evaluation studies to facilitate use of aluminum extrusions as a bridge decking material.

\section{CRADA BENEFIT TO DOE}

Test results, methods development, and analytical evaluation of test information were performed to aide in the use of aluminum extrusions and epoxy'-pea gravel wear surface composites as bridge decking materials.

\section{TECHNICAL DISCUSSION}

Work performed by ORNL is discussed in the abstract given above. Reynolds Metals Company prepared and tested some of the specimens referred to in the above studies. Further, they conducted wear surface durability, full deck panel tests, as well as developed the specific deck designs of several bridges now in service.

\section{INVENTIONS (MADE OR REPORTED)}

No inventions were made or reported, however, primary focus was upon test method and data development as well as using unique capabilities existing at ORNL. Reynolds Metals put several bridge decks in service which will be monitored over the long term to confirm expected durability.

\section{COMMERCIALIZATION POSSIBILITIES}

Several highway bridges are now in service using technology developed under this CRADA agreement.

\section{PLANS FOR FUTURE COLLABORATION}

Reymolds Metals Company has had a change in direction with respect to projects they are planning to pursue. Their present plans do not envision fabrication of aluminum extrusions for use as bridge decking.

\section{CONCLUSIONS}

A number of projects developed under this CRADA were successfully concluded which should further facilitate use of aluminum extrusions as a bridge decking material. These projects included results from surface durability studies, mechanical properties testing of welded and bolted joints, non-destructive evaluation of aluminum epoxy interfaces and welded joints, and use of turn-of-nut method for slip-critical joints. 


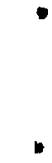




\section{REFERENCES}

1. W. Wright, "Building the Bridge to the $21^{\text {st }}$ Century with Aluminum," Public Roads, Spring 1997, pp. 30-33.

2. J. P. Stizak, B. Gieseke, and C. R. Brinkman, Fatigue Life of Several Mechanical Joint Designs in Support of Aluminum Bridge Deck Systems, ORNL/TM-13291, Oak Ridge National Laboratory, Sept. 30, 1996.

3. E. A. Payzant and C. R. Hubbard, Neutron Diffraction Strain Mapping In the Reynolds Bridge Deck Structure, Letter Report, Oak Ridge National Laboratory, March 1998.

4. W. R. Hendrich, Summary Letter Report on RMC Bridge Deck Wearing Surface Tests," Oak Ridge National Laboratory, May I, 1996.

5. W. R. Hendrich, Report of Reynolds Metals Company CRADA on Bridge Deck Wearing Surface Studies, ORNL/TM-1999/68 Oak Ridge National Laboratory, May 1999.

6. C. R. Luttrell, Investigation of Turn-of-Nut Method for Slip Critical Joints of Aluminum Using A325 Bolts, Oak Ridge National Laboratory Letter Report, January 1998.

7. J. P. Strizak, C. R. Brinkman, and G. M. Ludtka, Plate Weldment Flexural Fatigue Tests in Support of Advanced Aluminum Bridge Deck Design, ORNL/TM-1999/67, Oak Ridge National Laboratory, May 1999. 
$\checkmark$

.

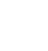

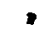




\section{INTERNAL DISTRIBUTION}

1

2.- 6 .

7.

R. A. Bradley

$8 . \quad$ L. B. Dunlap

9. H. W. Hayden, Jr.

10. W.R. Hendrich

$11 . \quad$ L. L. Horton

12. J. F. King

13. G. M. Ludtka

$14 . \quad$ C. R. Luttrell

$15 . \quad$ T. L. Payne

16-17. J. P. Strizak

$18 . \quad$ G. T. Yahr

19. ORNL Central Research Library

$20 . \quad$ Document Reference Section

21.- 22. Laboratory Records, ORNL-RC

23.- 24. Office of Scientific \& Technical Information

\section{EXTERNAL DISTRIBUTION}

12.- 29. Brian Malloy

Reynolds Metals Company

13203 N. Enon Church Road

Chester, VA 23836-3122

30. Mark Walker

Reynolds Metals Company

13203 N. Enon Church Road

Chester, VA 23836-3122

31. Larry Shives

6603 West Broad Street

Richmond, VA 23230 